
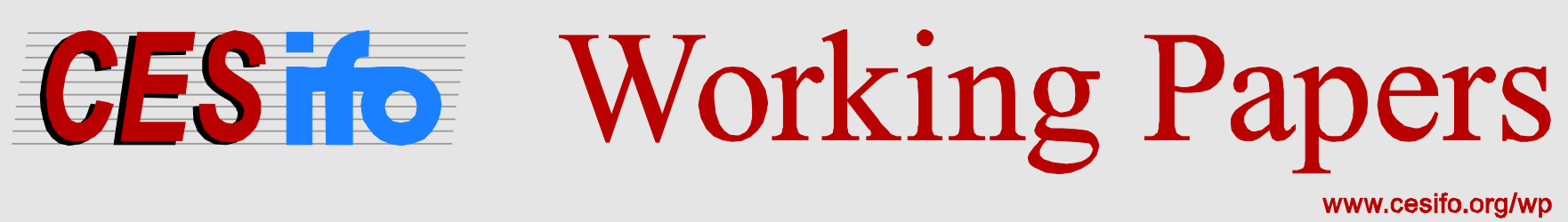

\title{
Taxation and the Multinational Firm
}

\author{
Peter H. Egger \\ Michael Stimmelmayr
}

\author{
CESIFO WORKING PAPER NO. 6384 \\ CATEgory 8: TRAde Policy \\ FEBRUARY 2017
}
An electronic version of the paper may be downloaded
- from the SSRN website: Www.SSRN.com
- from the RePEc website: Www.RePEc.org
- from the CESifo website: www.CESifo-group.org/wp




\title{
Taxation and the Multinational Firm
}

\begin{abstract}
This chapter provides a survey of issues which emerge with the taxation of multinational enterprises. It addresses tax rates which affect multinational firms directly and focuses on provisions and incentives which relate to the profits and investments of such firms directly. It survey positive as well as normative principles of such taxation and incentives, relates to taxavoidance practices, and discusses their remedies.
\end{abstract}

JEL-Codes: F210, F230, H250, H260.

Keywords: taxation, foreign direct investment, multinational firms.

Peter H. Egger

ETH Zurich, Department of Management, Technology, and Economics

Leonhardstrasse 21

Switzerland - 8092 Zurich

egger@kof.ethz.ch
Michael Stimmelmayr

ETH Zurich, Department of Management,

Technology, and Economics

Leonhardstrasse 21

Switzerland-8092 Zurich

stimmelmayr@kof.ethz.ch

The paper is forthcoming in: Batiz, F. R. and Spatareanu, M., (2017), Encyclopedia of International Economics and Global Trade, Vol. 4, Foreign Direct Investment, World Scientific Publishers. 


\section{Overview}

1. Introduction

2. Taxes that directly affect multinational firms and their effect:

a. Profit taxes, tax incentives towards tangible (capital) and non-tangible (R\&D) investments, and labor taxes.

b. Effect of taxes on multinational outcomes: investment and location.

c. Further aspects of the effect of taxation on multinational firm behavior.

3. The general issue with taxation and cross-border firm activity: double taxation.

a. Modes of double-tax relief: exemption, credit, and deduction.

b. The problem of double non-taxation of cross-border firm activity.

4. Normative Stance: Desirable attributes of systems of taxing foreign source income.

5. Bilateral tax law as a remedy of double taxation:

a. Behavior addressed: interest, profit repatriation, royalties.

6. Forms and remedies of multinational tax avoidance:

a. Profit shifting: transfer pricing, debt shifting, and other forms of profit shifting

b. Bargaining with home- and host-country governments.

c. Remedies of tax avoidance: transfer-pricing rules, controlled-foreign-company legislation, and thin-capitalization rules.

7. Conclusion 


\section{Introduction}

Over the last years, several big companies, including Apple, Amazon, Facebook, Google, IKEA, McDonald, and Star Bucks, among others, made the headlines with being accused of their aggressive tax avoidance strategies which had resulted in an exceptional disparity between company profits and taxes payed. As uncovered by The Guardian, for the UK case,

"Starbucks had paid £8.6m in corporation tax in its 15 years of trading in Britain, and nothing in the last three years despite overall sales of £3bn. Amazon, which had book and CD sales in Britain of $£ 3.35 b n$ in 2011, only reported a "tax expense" of $£ 1.8 m$ while Google's British business paid £6m to the Treasury in 2011 on UK sales of £395m.” (Macalister, 2013)

Later on, the publication of Luxemburg Leaks in April 2014 and The Panama Papers in April 2016 provided further insights in how multinational enterprises (MNEs) actually design their tax avoidance strategies. For the European Union as a whole, corporate tax-dodging costs are estimated between 50 to 70 billion euro (US $\$ 54.5$ to 76.4 billion) each year, much of it from profit-shifting (Dover, Ferrett, Gravino, Jones, and Merler, 2015). For the US, this figure is even higher and ranges between US \$77 and 111 billion per annum (Clausing, 2016). Against this background, it is not surprising that the taxation of multinational companies has more and more attracted public attention and has become one of the most salient issues in international tax policy.

This chapter provides a survey of issues which emerge with the taxation of multinational enterprises. The following section addresses those taxes which directly affect MNEs, as summarized in the effective marginal tax rate and the effective average tax rate, and the effect of these taxes on MNE behavior with a special emphasis on MNE investment and location. The section is completed by a discussion on MNE specific characteristics, such as the interrelation between MNE affiliates, and the impact of these characteristics on the effects of taxation. Cross-border firm activity and the problem of double taxation are subjects of interest to Section 3 of this chapter. Simple formal identities are derived to illustrate the emergence of double or multiple taxation in case all jurisdictions where a MNE operates exercise their right of taxation. As a remedy to double taxation, the different methods of double tax relief, including the exemption, the credit, and the deduction method are discussed. The last part of Section 3 is dedicated to the double non-taxation of foreign source profits, a recent phenomenon which has become relevant due to hybrid firm entities and hybrid financial instruments which are inconsistently characterized by taxing jurisdictions. Section 4 provides a normative stance on the issue of how foreign source income should be taxed. It starts with introducing the well-founded principles of capital export neutrality, capital import neutrality, and national neutrality, and additionally approaches the recent concepts of capital ownership neutrality and national ownership neutrality which additionally account for the fact that the location and ownership of capital is nowadays often separated. Actual policies against the double taxation of foreign source income, namely bilateral tax law in the form of double tax treaties, are the 
subject of interest to Section 5 of this chapter. In this section, the nature of double tax treaties and the economic behavior addressed in bilateral tax law is discussed. Besides the problem of double taxation and its remedies, Section 6 focuses on tax avoidance behavior of MNEs and policy measures against it. In the first part of Section 6, it is explained how MNEs take advantage of their multinational structure to benefit from tax rate differential across countries through transfer pricing, debt shifting or other forms of profits shifting, includes the re-location of intellectual property to low tax jurisdictions. Thereafter, different measures, including transfer-pricing rules, controlled-foreign-company legislation and thincapitalization rules, which rank among the most prominent policy instruments developed for combating tax avoidance behaviors of MNEs, are discussed. Section 7 concludes.

\section{Taxes that directly affect multinational enterprises and their effect}

\section{2a Profit taxes, tax incentives towards tangible (capital) and non-tangible (R\&D) investments, and labor taxes}

Among tax policy instruments which induce effects on MNE outcome, one may distinguish between ones that induce indirect effects and ones that induce direct effects. The present chapter focuses on instruments with a purpose to directly (even if not only) affect MNEs.

Among those taxes, ones on profits as well as tax incentives towards tangible (capital) and intangible (R\&D) investments feature most prominently. To see this, it is useful to introduce two effective (exante) tax concepts, the effective marginal tax rate (EMTR) and the effective average tax rate (EATR). The EMTR is the effective tax rate which applies to a marginal dollar earned on top of the average profits for a firm in a country (and year), and the EATR is the average tax rate on profit income of that firm. In broad terms, the EMTR is defined for the average firm in country $i$ and year $t$ as:

$$
\operatorname{EMTR}_{i t}=\left(1-A_{i t}\right) /\left(1-\tau_{i t}\right),
$$

where $A_{i t}$ is the present-discounted value of all after-tax costs net of depreciation allowances, tax credits, and other tax incentives towards tangible or intangible investments, depending on the investment project analyzed, and $\tau_{i t}$ is the respective statutory tax rate. The higher the EMTR, the higher are the after-tax costs for a firm from a marginal investment. Defining the difference between the pre-tax and after-tax nominal net-present values of a hypothetical investment in one period by $\Delta_{i t}$, and using $r_{i}$ and $p_{i}$ to denote the (time-invariant, long-run) real interest and inflation rates in country $i$, respectively, the EATR is defined for the average firm in country $i$ and year $t$ as:

$$
\operatorname{EATR}_{i t}=\Delta_{i t}\left(1+r_{i}\right) / p_{i}
$$

The term $\Delta_{i t}$ is itself a function of $r_{i}$ and $p_{i}$ and of the financing opportunities of the investment - most commonly retained earnings, new equity, and debt - and their tax treatment. 


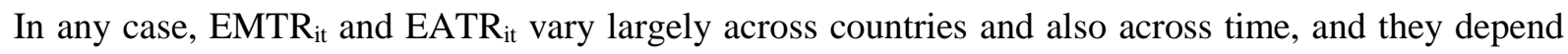
nonlinearly on the statutory tax rate as well as investment incentives (see Devereux and Griffith, 1998b, 2003; Egger, Loretz, Pfaffermayr, and Winner, 2009b). Effective tax rates are commonly computed according to the above formulae and used in empirical work to explain MNE outcome. The problem with this practice is that these tax rates are computed for firms that are held and operating in country $i$ (i.e., national rather than multinational in scope). However, bilateral tax law leads to modifications of the respective tax rates for MNEs and, in fact, such tax rates vary eventually by country pair in a given year $t$ and for a headquarters country $i$ (see Egger, Loretz, Pfaffermayr, and Winner, 2009a). This is typically not done in empirical work and, hence, the estimates of tax sensitivities of MNEs the literature provides may be prone to parameter bias flowing from measurement error about effective tax rates (see Egger, Loretz, Pfaffermayr, and Winner, 2009a).

Labor-tax law is important for MNEs in particular to the extent that MNEs use expatriates to conduct some of the high-skilled-labor-intensive tasks (see Bergstrand, Egger, and Larch, 2008), and many countries provide special tax deals for expatriates either in their unilateral tax law (see, e.g., the Netherlands) or in their bilateral tax treaties. Usually, what countries provide to expatriates are flat rates or special treatments through deductions and allowances.

\section{2.b Effects of taxes on multinational-enterprise outcomes: investment and location}

A country's capability to attract foreign direct investment (FDI) depends on several factors. A large body of literature shows the existence of statistically significant and quantitatively important tax effects on the magnitude and location of FDI. An in depth survey on the earlier and more recent literature in this field is provided by Hines (1997 and 1999) and De Mooij and Ederveen (2003).

The early studies, starting with Hartman (1984), analyze the responsiveness of FDI flows with regard to annual changes in the after-tax rate of return. The studies find a positive correlation between FDI and after-tax rates of return and report an elasticity of around one, which corresponds to a tax elasticity of investment of roughly -0.6 (see Hines, 1999). The data used in these early papers are, however, highly aggregated, and thus potentially suffer from several problems. Most likely, the high level of aggregation might induce an omitted-variables bias. Therefore, it becomes questionable if the mentioned studies were able to distinguish the effects of taxation on FDI from other variables that are correlated with tax rates (Hines, 1999). Later studies, resorting to bilateral FDI flow data or micro-level data on MNEs' affiliates, pay explicit attention to these problems.

Hines (1996), for instance, analyses data on property, plant and equipment investment of foreign countries in the United States (US) and finds a significant negative effect of US states taxes on the allocation of FDI among US states. Gorter and Parikh (2000) and Benassy-Quéré, Fontagné, and Lahreche-Révil (2003) follow a similar approach using panel data on bilateral FDI flows between 
Organization for Economic Co-Operation and Development (OECD) countries and as well report a significant tax effect on FDI. A consensus estimate, reflecting the findings of most of the empirical literature over the last decades, culminates in an elasticity of FDI with regard to taxation of around -0.6 (see Hines, 1999; and De Mooij and Ederveen, 2003). Accordingly, a 10 percent increase in a country's tax rate reduces FDI by 6 percent. Further, the work by Gorter and De Mooij (2001) suggests that intraEuropean investment flows tend to be more responsive to tax-rate differentials than intercontinental flows.

Other studies, including Grubert and Mutti (1991, 2000) and Hines and Rice (1994) or Altshuler, Grubert, and Newlon (2001) resort to micro-level data of US MNEs and analyze the effect of differences in corporate tax rates around the world on the cross-sectional distribution of US outbound FDI in the form of property plant and equipment. Altshuler, Grubert, and Newlon (2001) find that the absolute magnitude of the elasticity of US outbound FDI with regard to a country's tax rate has increased substantial in the analyzed period, namely from -1.5 in 1984 to -2.8 in 1992.

Desai, Foley, and Hines (2004) provide evidence of a negative impact of indirect taxes, such as sales, value added, excise, and property taxes as well as import and export duties, on FDI that is comparable in magnitude with the negative effect of corporate income taxes on FDI. Specifically, the authors find that US affiliates have 7.1 percent lower assets if located in countries with 10 percent higher indirect tax rates, whereas the respective drop in affiliates' assets due to 10 percent higher income taxes amounts to about 6.6 percent. These lower investment levels are also reflected in lower affiliate output. 10 percent higher indirect tax rates result in a roughly 2.9 percent lower output while the same increase in income tax rates implies a 1.9 percent lower output. One important difference in the effect of indirect vs. income taxes emphasized by Desai, Foley, and Hines (2004) is that higher corporate income taxes negatively affect affiliates' capital-labor ratios and profit rates, whereas no such depressing effect is found for higher indirect taxes.

In addition to the cross-sectional estimates on the effect of taxes on FDIs, several papers explicitly study the effect of taxation on the location decision of foreign affiliates. Devereux and Griffith (1998a) is one of the first studies in this filed and analyzes the location decision of US MNEs in several large European countries over the period 1980-1994. They find that the choice of location is significantly influenced by the host country's effective average tax rate rather than the effective marginal tax rate, as predicted by theory. Büttner and Ruf (2007) investigate the location of FDI of German MNEs in 18 foreign countries over an 8-year period. Their findings suggest that the location decision is especially sensitive to the statutory (but not the effective average) tax rate of the potential location, besides market size (approximated by GDP) and labor costs. Their results indicate that, for an investment with a 50 percent chance of being carried out at the current tax rate in a given location, an increase in the statutory tax rate 
by 10 percentage points in that location reduces the probability of the investment being carried out by one fourth, i.e., 12.5 percentage points. This suggests that taxes are similarly important for the location decision as differences in labor costs. Resorting to a similar data base on outbound FDI of German MNEs as used in Büttner and Ruf (2007), Hebous, Ruf, and Weichenrieder (2010) estimate the effect of differences in international statutory tax rates on the location decision of FDI in the form of either greenfield vs. mergers-and-acquisitions (M\&A) FDI. After controlling for firm- and country-specific characteristics, they find that an increase in the statutory corporate tax rate of 10 percent reduces the probability of that country being chosen as the host of a greenfield investment by 6.4 percent, while the respective estimate for the M\&A investment amounts to only 3.6 percent. The result of a significantly higher tax sensitivity of greenfield vs. M\&A FDI is in line with Swenson (2001), who finds that US states taxes have a strong negative effect on inbound greenfield investment, but a positive (yet not significant) effect on inbound M\&A investment. Barrios, Huizinga, Laeven, and Nicodème (2012) study the impact of three different layers of taxation, namely, (i) the host country's tax rate, (ii) the host country's withholding tax on dividend distributions to non-residents, and (iii) the repatriation tax of the parent country, on the location choice of a new foreign subsidiary of an MNE. Their data set includes 33 European countries, so that every investor has a potential choice between 32 foreign locations. The estimated effects suggest that a 10 percentage point increase in the host or parent country tax rate reduces the probability of location by 9.0 and 10.7 percent, respectively, whereas withholding taxes on distributed dividends have no significant effect. Furthermore, Barrios, Huizinga, Laeven, and Nicodème (2012) find that that highly profitable foreign subsidiaries are less sensitive to host and parent country taxation what they attribute to location specific rents which are lost in case of re-location. This result bears resemblance with the insight offered in Kind, Midelfart Knarvik, and Schjelderup (2000) that agglomeration rents make firms less sensitive to taxes and in the end allow government to levy higher taxes (see also Baldwin and Krugman, 2004).

The financing of FDI (related to the use of internal debt finance) and the role of taxes are discussed in Section 5 of this chapter.

\section{2.c Further aspects of the effect of taxation on MNE behavior}

There is a recent strand of literature which highlights the importance of interrelations among affiliates for the effect of taxes on MNE behavior. Multinationals set themselves apart from stand-alone firms by using a common set of input factors or by establishing internal markets to potentially overcome frictions in external markets. Nielsen, Raimondos-Möller, and Schjelderup (2010) show that the provision of a common input (e.g., blue prints) by the headquarters of an MNE gives rise to a co-movement in affiliates capital stocks and a complementarity in the response to higher corporate taxes in one affiliate's location. Egger, Merlo, Keuschnigg, and Wamser (2014) and Koethenbuerger and Stimmelmayr (2016a) develop 
a corporate agency model where divisions of an MNE are linked via an internal capital market and managerial effort provision affects the amount of funds available in the internal capital market. The internal capital market creates efficiency costs and thereby resource linkages across affiliates of the MNE which introduce a tendency that divisional capital stocks co-move in response to a higher tax in one affiliate location. The findings provide an explanation for the observation that there is not necessarily a tax-induced substitution between capital stocks of divisions of an MNE or that capital stocks are even complements (see Desai, Foley, and Hines, 2005 and 2009, for instance). Similarly, Becker and Riedel (2012) find evidence that taxes in the parent country of the MNE reduce affiliate investment abroad. A parent tax increase by ten percentage points dampens affiliate investment by 5.6 percent.

Furthermore, as surveyed by Desai and Dharmapala (2008) corporate agency problems play a nonnegligible role in determining the effects of taxation on MNE behavior. In this spirit, Elitzur and Mintz (1996) set up a model of MNE behavior in which an affiliate manager exerts costly effort to reduce costs of production. The interrelation between transfer pricing and agency cost consideration might lead corporate taxes to be too high from a social perspective. Koethenbuerger and Stimmelmayr (2016b) analyze how the mode of determining transfer prices (centralized choice vs. bargaining among division managers) is determined by agency costs and taxes. The importance of effort provision due to bargaining and the benefits of tax avoidance due to a centralized choice of the transfer price do not always tradeoff in the determination of the optimal mode of transfer pricing. An MNE might well favor a centralized choice of the transfer price to provide stronger managerial incentives and to have a more direct control over tax avoidance behavior.

\section{The general issue with taxation and cross-border firm activity: double taxation of foreign source income}

The introductory chapters of the handbook discuss the empirical relevance and the determinants of FDI. Independent of its motive or form (greenfield vs. brownfield investment), FDI inherently involves a cross-border activity of a firm where the tax systems of more than one country matter.

To shed light on the basic issue of cross-border firm activity and double taxation, a firm conglomerate consisting of a parent firm (the headquarters) located in country A and one subsidiary located in country $\mathrm{B}$ (the foreign affiliate or FDI) is considered. The issue is how the profits of the conglomerate should be treated for tax purpose. One possibility is that profits of each unit are taxed in that jurisdictions where the entity is located, that is, at "source". Under source taxation, the parent profit, $\pi_{\mathrm{A}}$, is subject to taxation in country $\mathrm{A}$ at a rate $\tau^{\mathrm{A}}$ whereas the profit of the subsidiary, $\pi_{\mathrm{B}}$, is taxed in country $\mathrm{B}$ at a rate $\tau^{\mathrm{B}}$. The net-of-tax profit of the MNE is then given by: 


$$
\Pi=\left(1-\tau^{A}\right) \pi_{A}+\left(1-\tau^{B}\right) \pi_{B} .
$$

Another possibility is that the consolidated profit of the conglomerate, $\left(\pi_{\mathrm{A}}+\pi_{\mathrm{B}}\right)$, is only taxed in country A, the "residence" or (home or parent) country of the MNE. In this case, the net-of-tax profit of the conglomerate is given by:

$$
\Pi=\left(1-\tau^{A}\right)\left(\pi_{A}+\pi_{B}\right),
$$

assuming that the subsidiary's profits are not taxed in country B. In either of both cases, profits of the conglomerate are taxed only once.

Country B might, however, exercise its right of taxing the profits $\pi_{\mathrm{B}}$ generated within its jurisdiction. If country A additionally taxes the consolidated income of the conglomerate, a double taxation of foreign source profits emerges: the profit of the subsidiary is once subject to the corporate tax levied in country $\mathrm{B}$ and, again, subject to taxation in country A, when consolidated profits of the conglomerate are taxed. In this situation, after-tax profits of the MNE are:

$$
\Pi=\left(1-\tau^{A}\right) \pi_{A}+\left(1-\tau^{A}-\tau^{B}\right) \pi_{B} .
$$

In general, double taxation characterizes the situation where an MNE's income earned from an economic activity in a foreign country is taxed at least twice. The double taxation of foreign source profits constitutes an impediment to FDI and places MNEs at a disadvantage vis-à-vis national firms, which are taxed only once. Additional negative consequences associated with the double taxation of foreign source profits involve an inefficient international allocation of capital and other production factors, a distortion in the ownership structure of assets, and a sub-optimal savings and investment behavior. Moreover, the double taxation of profits amplifies the incentives for tax evasion and tax avoidance.

To avoid these negative consequences associated with the double taxation of foreign source profits, governments regularly sign double-tax treaties regulating the method of double taxation relief. Articles 23A and 23B of the OECD Model Tax Convention (OECD, 2015) portray the two most commonly applied methods for eliminating double taxation. These are the exemption method and the credit method. There exists a third method, the deduction method, which is less frequently used in practice and it does not fully avoid double taxation of foreign source income (see Davies, 2003, 2004). For completeness, it is also reviewed in following section.

\section{3.a Modes of double-tax relief: exemption, credit, and deduction}

The above examples of taxing foreign source income represent the two basic approaches applied in real world, i.e., the source principle, also referred to as a territorial tax system, and the residence principle, which is often referred to as a system of taxing worldwide income.

Under the source principle (the territorial tax system), a country levies a tax on income generated within the borders of its jurisdiction, i.e., a source inside the country. Additionally, foreign source income 
which is repatriated to a country applying the source principle is usually exempted from taxation to avoid double taxation of foreign source income. Thus, the source principle and the exemption method usually go hand in hand.

a) Exemption Method:

The simplest way to avoid double taxation of cross-country profits is to exempt foreign source income from domestic taxation. Against the background of the above example, the exemption method implies, that subsidiary profits already taxed in country B, are exempted from taxation when consolidated profits are calculated. Accordingly, under the exemption method, after-tax profits of the MNE are:

$$
\Pi=\left(1-\tau^{A}\right) \pi_{A}+\left(1-\tau^{B}\right) \pi_{B} .
$$

Foreign subsidiary profits, $\pi_{B}$, are excluded from the tax base in the parent country of the MNE.

From a global perspective, the source principle with an exemption of foreign source income creates inefficiencies in the international allocation of capital. Assuming a world of two countries both of which have a territorial tax system in place (i.e., apply the source principle) and foreign source income is tax exempted, the after-tax rates of return on investments differ among locations and they are independent of the parent country of the investor. Arbitrage ensures that the after-tax rates of return are equalized across countries, whereas the gross rates of return, i.e., the marginal products of capital, do not equalize across countries if countries' tax rates differ. Hence, differences in tax rates across countries matter under the source principle and low-tax countries are able to attract larger shares of internationally mobile capital due to the lower tax cost. However, one important positive aspect associated with the system is that the tax costs for a national and an international investor operating in the same country are equalized and all firms compete on a level playing field. The empirical relevance of the territorial system approach has changed substantially over the last decade. As of the year 2000, only 14 out of the current 34 OECD member countries had implemented a territorial system. In 2012, that number was 28 OECD member countries (PWC, 2013).

Contrary to the source principle, under the residence principle (a system of worldwide taxation), consolidated income of a domestically-headquartered MNE is subject to taxation in the parent country of the MNE. The residence principle, thus, implies a double taxation of foreign source income, especially, in the situation when foreign countries execute their right of taxing the income generated by those foreign firms they host. To avoid the double taxation of foreign source income when worldwide income is subject to taxation, countries applying the residence principle usually grant a credit for the taxes paid to a foreign government. In case an unlimited foreign tax credit is granted, the credit method ensures that every investor residing in that country faces an equal tax treatment of her business activity, independent of the location (home or abroad) where the investment takes place.

b) Credit Method: 
Countries having a worldwide tax system in place predominantly apply the credit method to mitigate the double taxation of foreign source profits. Under the credit method, the parent country of the MNE taxes worldwide income of the firm conglomerate, but grants a tax credit in the size of the foreign tax due. Thus, the after-tax profit of the MNE is:

$$
\Pi=\left(1-\tau^{A}\right) \pi_{A}+\left(1-\tau^{A}-\tau^{B}\right) \pi_{B}+\tau^{B} \pi_{B} \text {, or simply } \Pi=\left(1-\tau^{A}\right)\left(\pi_{A}+\pi_{B}\right) .
$$

In case the foreign tax rate is lower than the domestic one, $\tau^{A}>\tau^{B}$, an additional tax due arises on foreign-earned income when repatriated. If the parent country levies a tax rate lower than the foreign country, $\tau^{A}<\tau^{B}$, the MNE earns an excess foreign tax credit which may reduce prior-period taxes (carry back) or future-period taxes (carry forward). Excess foreign tax credits and carry back / forward might be limited, depending on a country's tax law.

The credit method ensures that the investor residing in a given country faces the same after-tax rate of return on the investments, independent of the location of the investment. Therefore, the tax does not distort the location decision of the investor. Arbitrage ensures that the after-tax rates of return are equalized and given that the arising tax wedge is the same independent of the investment location, the gross rates of return, i.e., the marginal products of capital, are as well equalized across countries. Thus, a system of worldwide taxation combined with the credit method implies an efficient international allocation of capital. The most prominent country still having a worldwide tax system in place are the US.

For reasons of practicability, foreign source income is, under the residence principle, taxed by the parent country mostly upon repatriation rather than accrual, allowing for a tax deferral until repatriation actually occurs. This feature generates a lock-in effect and empirical evidence shows that MNEs have an incentive to not repatriate offshore profits earned in a low-tax jurisdictions in order to avoid the taxation upon repatriation. Often, these offshore profits are argued to be re-invested abroad, even if investment opportunities are limited, and may earn a lower pre-tax rate of return compared to investment alternatives at home. In fact, Foley, Hartzell, Titman, and Twite (2007) document that US-based MNEs with higher tax costs of channeling foreign funds to US divisions keep higher levels of funds abroad. Harford, Wang, and Zhang (2015) and Hanlon, Lester, and Verdi (2015) show that the market places a discount on these offshore funds. The size of the discount is related to the repatriation tax rate, an effect that rises with the severeness of agency conflicts within an MNE. Any inefficient re-investment of trapped offshore profits abroad can be perceived as an actual distortion in the investment location. Thus, the practice of taxing foreign source income and granting the foreign tax credit upon repatriation undermines the neutrality result with regard to the location decision which is conceptually associated with a system of worldwide taxation with unlimited foreign tax credits.

c) Deduction Method:

Both the exemption method and the credit method prevent the double taxation of foreign source income. 
A third method, which is, however, less frequently used in practice and does not fully eliminate the double taxation of foreign source profits, is the deduction method. Under tax deduction, the parent country of the MNE grants the tax deductibility of the foreign tax due. Foreign taxes are perceived as normal costs, similar to, for instance, labor costs, and enjoy therefore for the same reasons tax deductibility. The MNE's tax dues in country A and B are:

$$
T^{A}=\tau^{A}\left(\pi_{A}+\pi_{B}-\tau^{B} \pi_{B}\right), \text { and } T^{B}=\tau^{B} \pi_{B},
$$

respectively and, hence, after-tax profits of the MNE are given by:

$$
\Pi=\left(1-\tau^{A}\right) \pi_{A}+\left(1-\tau^{A}\right)\left(1-\tau^{B}\right) \pi_{B} .
$$

As a result of the deduction method, arbitrage equates the gross rate of return in country A with the after-tax rate of return in country B. This outcome implies, from a global perspective, an inefficient allocation of capital with too much capital invested in country A. From country A's, perspective, the capital allocation is, however, optimal because the amount of income earned on the marginal investment at home (consisting of tax revenues and after-tax income) and abroad (consisting of after-tax income) is equalized. Any re-shuffling of domestically owned capital cannot increase domestic income. We will return to this issue in Section 3 of this chapter.

Despite theoretical work on the efficiency implications of the different methods of avoiding double taxation (see Section 3 of this chapter), there is little positive evidence on the effects arising when countries switch between systems. The few exceptions include recent papers by Egger, Merlo, Ruf, and Wamser (2015), Hasegawa and Kiyota (2015) and Feld, Ruf, Scheuering, Schreiber, and Voget (2016). Egger, Merlo, Ruf, and Wamser (2015) analyze the behavioral responses of foreign affiliates of UKowned versus non-UK-owned MNEs due to the switch from the tax credit to the tax exemption method in the United Kingdom (UK) in 2009. The results suggest that the reform induced the average UKowned affiliate to pay out roughly 35 percent more dividends, about US\$2,15 million, compared to the counterfactual affiliate which is not affected by the reform. The increase in dividend repatriations confirms the theoretical insights stating that a switch from the tax credit to the tax exemption method may imply a substantial tax cut on foreign source income generated in locations featuring a lower tax rate than the one in the UK. Another remarkable finding by Egger Egger, Merlo, Ruf, and Wamser refers to the real outcomes resulting from the reform: the average UK-owned affiliates cut investment by about US\$3.05 million and thus invests about $88 \%$ less than the counterfactual affiliates in response to the reform.

In a similar vein, Dharmapala, Foley, and Forbes (2011) investigate the effects of the US Homeland Investment Act which provided a tax holiday for the repatriation of foreign earnings. Their paper shows that the tax holiday substantially increased repatriations but repatriations did not increase domestic (US) 
investment, as supporters of the Act initially claimed to make the Act pass the US Congress. Instead, a $\$ 1$ increase in repatriations was associated with a \$0.60 to \$0.92 increase in shareholder pay-outs.

In 2009, Japan switched from the tax-credit to the tax-exemption method. Hasegawa and Kiyota (2015) analyzed this event. They found that dividend repatriation become more sensitive to withholding taxes levied on dividends after the adoption of the territorial tax system, but they were not able to identify a strong impact on dividend repatriations of foreign affiliates of Japanese MNEs in response to the reform. Feld, Ruf, Scheuering, Schreiber, and Voget (2016) analyze the effect resulting from the switch from the tax credit system to the exemption system in Japan, New Zealand, and in the United Kingdom (UK) on the market for corporate control. Investors residing in countries which apply the credit system face a comparative disadvantage vis-à-vis investors residing in countries using the exemption method, because foreign source income of the former is additionally subject to the repatriation tax while the one of the latter is not. In line with this insight, the authors find that the switch from the tax-credit to the taxexemption method raised foreign acquisitions by Japanese, New Zealand and British firms by 16.1, 1.8, and 1.6 percent, respectively.

\section{3.b The problem of double non-taxation of cross-border firm activity}

While the double taxation of MNE profits is perceived as a severe problem, the double non-taxation of foreign source income is identified as equally problematic. The rationale is based on the fact that the double non-taxation of firm profits distorts competition, because it grants a competitive advantage to MNEs but not to national firms that are subject to ordinary taxation. Different mechanisms which may result in a double non-taxation of foreign source profits are reviewed in European Commission (2012).

The vehicles most commonly used to exploit the double non-taxation of profits include hybrid firm entities and hybrid financial instruments. A hybrid firm entity is an entity which is inconsistently characterized by domestic and foreign tax law resulting in a diverging, jurisdiction-dependent tax treatment. Specifically, hybrid entities take advantage of being classified as a transparent (tax-exempt) entity in one country but a non-transparent (taxable) entity in another country. For instance, if the subsidiary in country B is a hybrid entity which is seen as transparent in country B but as non-transparent in country A, where the parent resides, double non-taxation may occur. That is, the income of the hybrid entity is tax exempt in country B, as it is seen as transparent, and repatriated profits of the hybrid subsidiary may be non-taxed in the parent country, if country A has a territorial tax system in place where foreign source income is tax exempted.

Hybrid financial instrument, likewise, takes advantage of the mismatch in the classification of debt and equity across different countries. For instance, if a hybrid financial instrument is classified as debt in country B and as equity in country A, a double non-taxation of firm profits becomes feasible. Assume the subsidiary in country B finances its investment using the hybrid instrument. Then, the subsidiary 
benefits from interest deductions eliminating the corporate tax burden in country B. Additionally, the return on the hybrid financial instrument earned in the parent country of the MNEs is perceived as a return to equity, i.e., dividends (instead of interest income), and is thus tax exempted, in case country A has a territorial tax system in place.

Johannesen (2012, 2014) develops a model of hybrid instruments and studies the conditions under which tax avoidance is practicable with such hybrid instruments. In essence, the papers show that demarcation rules determine whether a country classifies an instrument as debt or equity and if these demarcation rules are set sufficiently different among countries, tax avoidance with hybrid instruments always becomes feasible along the lines described above. Johannesen (2014) additionally shows why countries may have an incentive to permit tax avoidance with hybrid instruments. In an uncoordinated equilibrium without any anti-avoidance measures, the disallowance of hybrid instruments by a single country would be detrimental for that country, because not allowing the hybrid instruments implies an effective taxation of the MNE's operation in that country. The incidence of the tax is, however, solely borne by the immobile workers of the country itself since the MNE shifts production to another host country where hybrid instruments are allowed. Further, a coordinated ban of hybrid instruments in all countries may result in positive tax revenues collected from MNEs but may as well induce tax competition, resulting in ambiguous welfare outcomes.

Further examples of how hybrid mismatch arrangements are exploited for tax avoidance and how countries respond to prevent the abuse of these arrangements are found in OECD (2012). The stake involved in single transactions exploiting hybrid mismatch arrangements may be substantial. Reported cases of tax avoidance involving hybrids amounted to EUR 1.3 billion in New Zealand, to approximately EUR 1.5 billion in Italy, and an amount of tax at stake of USD 3.5 billion in the US. ${ }^{1}$

Apart from hybrid mismatch arrangements the (ab-)use of double-tax treaties (DTTs), which have been established over the years and stipulate the bilateral or multinational double tax conventions, may also result in double non-taxation of foreign source profits - an outcome opposing the initial purpose of DTTs, which is a remedy for the double taxation of foreign source income; see Section 4.

\section{Normative stance: desirable attributes of systems of taxing foreign source income}

The various methods of avoiding double taxation of foreign source income result in different allocative consequences, depending on whether they achieve an equalization of the before- or after-tax rates of return in the different locations. In case both the before- and after-tax rates of return are equalized across

\footnotetext{
${ }^{1}$ The legal background giving rise to tax arbitrage by using hybrid financial instruments under the US tax system is elaborated by Krahmal (2005).
} 
countries, such as under worldwide taxation with the credit method in place, the investor's decision whether to invest in country A or B remains unaffected by the tax and an efficient international allocation of capital is guaranteed. If, however, only the after-tax rates of return are equalized, as it is the case under a territorial tax system where foreign source income is exempted, before-tax rates of return will differ, if country specific tax rates vary. In this situation, the tax does not discriminate between different investors (domestic vs. foreign), but the emerging capital allocation is distorted. This discussion raises the question how the existing system determining the taxation of foreign source income compares with optimal systems of international income taxation.

The existing literature, dating back to Richman (1963) and Musgrave (1969), provides several neutrality conditions which have been established postulating desirable outcomes international tax policy might aim to achieve.

The two most prevalent and influential concepts of taxing foreign source income are the concepts of capital export neutrality (CEN) and capital import neutrality (CIN), both developed by Richman (1963) and refined by herself in Musgrave (1969). Despite the many decades since these two concepts have been published, they have not yet become obsolete and still provide useful benchmarks for actual policy design. The principle of capital export neutrality (CEN) requires that the taxation of foreign source income does not distort an investor's decision where to locate her investment, i.e., whether to invest at home or abroad. Under this concept the taxation of foreign source income should not distort the outflow of capital to foreign countries. An investor residing in a given country, say country A, is indifferent between investing at home or abroad (country B), if the investment yields the same after-tax rate of return independent of the investment location, i.e., $\left(1-\tau^{A}\right) r^{A}=\left(1-\tau^{A}\right) r^{B}$. If after-tax rates of return are equalized, then, gross rates of return are equalized, and the marginal investment yields the same rate of return independent of the location decision. The capital allocation ensures that world output is maximized, i.e., any re-location of capital cannot increase world output and, hence, world production efficiency prevails.

CEN can be achieved under a system of worldwide taxation (residence principle) combined with an unlimited foreign tax credit. In case of territorial taxation where foreign source income is exempted from domestic taxation (source principle), CEN cannot be achieved unless tax rates are harmonized across countries. In general, CEN is associated with relatively high administrative costs, because the tax administration requires information on the foreign source income of residents which may not be automatically transmitted to the investors' parent country making it much easier and less costly for an investor to hide foreign vis-à-vis domestic income. This may, however, change in the future.

In 2005 the European Union (EU) launched a savings-taxation directive (Directive 2003/48/EC) to ensure an automatic exchange of information on private savings income between EU member states. 
The arrangement additionally involved a withholding tax to be deducted from interest income of EU residents earned in a foreign EU member state in order to mitigate tax evasion. The directive was repealed in 2015 and replaced by Directive 2014/107/EU which became effective from January 2016 onwards. The new directive strengthens global measures for preventing tax evasion further and includes dividends and other types of capital income, and the annual balance of the accounts producing such items of income, in addition to interest income. The automatic exchange of information stipulated in the directive follows the common reporting standard (CRS) developed by the OECD. In a similar vein, the US Foreign Account Tax Compliance Act (FATCA), enacted in 2010 requires foreign financial institutions to report on the foreign assets held by US residents. In addition to national and EU-wide regulations, the OECD Convention on Mutual Administrative Assistance in Tax Matters regulates information exchange between state parties on the exchange of information regarding tax matters. Most importantly, the OECD convention stipulates to transfer all the relevant information automatically and systematically, whereas in most existing treaties information was shared upon request. At the end of 2016, the OECD Convention is signed by all G20 countries, all BRIICS, all (non-G20) OECD countries, major financial centers, and an increasing number of developing countries (see http://www.oecd.org).

The concept of capital import neutrality (CIN) requires that an investor, independent of its country of residence, faces the same after-tax rate of return in a given country. Plainly, the inflow of capital towards a country should not be distorted due to a variation in the tax burden foreign investors face. Under a system of territorial taxation where foreign source income is tax exempted (source principle), CIN is met. An investor, independent of whether located in country A or B, earns an after-tax rate of return of $\left(1-\tau^{A}\right) r^{A}$ or $\left(1-\tau^{B}\right) r^{B}$, if investing in country A or country B, respectively. Thus, investors operate on a level playing field and foreign investors do not face a tax disadvantage vis-à-vis domestic investors under CIN. However, if tax rates differ across countries, i.e., $\tau^{A}>\tau^{B}$, the after-tax rates of return differ as well across countries and a tax-induced distortion in the international allocation of capital emerges. ${ }^{2}$ Specifically, capital is attracted to low-tax countries and the distortion in the capital allocation is larger, the greater the differences in tax rates are. The responsiveness of capital to tax rates also provides an incentive to governments to lower tax rates in fiscal competition (see Keen and Konrad, 2014, for a recent review of the literature). Despite the inefficient international allocation of capital, CIN bears much lower administrative costs compared to CEN because CIN neither requires information on the foreign income nor the foreign tax due of domestic investors. This might explain why the source-principle (ensuring CIN) is the dominant principle in practice.

\footnotetext{
${ }^{2}$ Additionally, the fact that an investor's activity in country A and country B is subject to different tax treatment under CIN violates the principle of horizontal equity in taxation, which requires that all activities of an investor residing in a given country are subject to the same tax treatment by that country.
} 
Straightforwardly, the requirements for CEN and CIN cannot be met simultaneously unless tax rates are harmonized across countries.

Different to CEN, which focuses on a global efficient allocation of capital, the concept of national neutrality (NN), developed by Feldstein and Hartman (1979), aims at a tax policy which maximizes national welfare. Under this concept, a distortion in the international allocation of capital is desired by a given country if this distortion raises national welfare. Specifically, from a national perspective the optimal allocation of capital is achieved, say, for country A, if the gross return on capital in country A equals the after-tax rate of return in the foreign country B, i.e., $r^{A}=\left(1-\tau^{B}\right) r^{B}$. Even though the marginal product of capital in country A is below the one in country B, re-shuffling capital from country A to country B is not beneficial for country A, because the after-tax return potentially earned in country $\mathrm{B}$ remains below the gross return (after-tax return plus tax revenues collected) earned in country A. The fact that an improvement in the capital allocation raises global output is irrelevant for country A under NN because country B is the sole beneficiary of the resulting output gain. National neutrality is achieved when a system of worldwide taxation (residence principle) or the deduction method is in place.

More recently, the existing neutrality postulates of CEN, CIN, and NN have been challenged by the concept of capital ownership neutrality (CON) and national ownership neutrality (NON), both developed by Desai and Hines (2003, 2004). These concepts build on the insight that FDI nowadays mostly takes the form of mergers and acquisitions and thus represents changes in the ownership of existing capital rather than a mere transfers of net savings across countries. Specifically, MNEs are typically recognized as more productive than domestic firms, since they are able to exploit intangible input factors through cross-border business activities (see Antràs and Yeaple, 2014, for a recent survey of the literature). This ownership advantage of MNEs drives mergers and acquisitions and is also reflected in the premium MNEs are willing to pay when conducting an FDI. As it states, this view is compatible with the notion of outbound FDI from high-income countries towards other capitalabundant, high-income countries, but it is hardly in line with the "old" idea of FDIs representing transfers of net savings to capital-scarce locations, as implicitly underlying the concepts of CEN, CIN, and NN. An important implication following from this approach is that the country-specific capital stocks are quasi fixed when FDI solely represent the re-allocation of ownership rights due to merger and acquisitions. (In detail, if greenfield investments are disregarded, the problem reduces to the efficient allocation of a given capital stock to investors who differ in productivity.) Against this background, the concept of ownership neutrality requires that an asset should reside with the investor who has the highest reservation price, i.e., the one who has the most productive use of that asset, independent of existing tax rules. Plainly, the taxation of foreign source income may not distort the international ownership of capital. In terms of the previous example, assume the MNE, which is headquartered in country A, owns 
an intangible asset, such as management know-how or a patent. The intangible asset grants the subsidiary in country B an ownership advantage vis-à-vis national firms located in country B. Denoting the ownership advantage by $\varepsilon$, the gross return earned by the subsidiary of the MNE on a particular asset in country $\mathrm{B}$ is given by $\widetilde{r^{B}}=r^{B}+\varepsilon$, whereas the national firm residing in country B earns a gross return of $r^{B}$. In the absence of taxation, the most productive owner, that is the subsidiary of the MNE, will also be the actual owner of that particular asset in country $\mathrm{B}$, given that she has the highest willingness to pay when acquiring the asset. Under the system of worldwide taxation with foreign tax credits, the optimal ownership of assets may be distorted, if tax rates between countries vary. Namely, the after-tax return on the asset located in country B and earned by the MNE headquartered in country A is given by:

$$
\left(1-\tau^{A}\right) \widetilde{r^{B}}=\left(1-\tau^{A}\right)\left(r^{B}+\varepsilon\right) .
$$

The after-tax return earned on the same asset by a national firm located in country B is $\left(1-\tau^{B}\right) r^{B}$. Hence, if tax rates are sufficiently different, i.e., $\tau^{A} \gg \tau^{B}$, the national firm earns a larger after-tax rate of return on the asset and will thus have a higher willingness to pay for the asset. Thus, the outcome that investors from different locations face a varying after-tax rate of return in a given country under the system of worldwide taxation with foreign tax credits may result in an inefficient ownership structure of assets. The fact that foreign source income is taxed by the home country only at the time when repatriated rather than accrued may, however, mitigate the tax-induced distortion in ownership.

On the contrary, a system of territorial taxation, where foreign source income is tax-exempt, clearly leaves ownership structures undistorted. Investors operate on a level playing field and face an identical tax burden on their foreign source income in a given country, independent of their parent country. That is, the after-tax rate of return earned by the MNE is given by:

$$
\left(1-\tau^{B}\right) \widetilde{r^{B}}=\left(1-\tau^{B}\right)\left(r^{B}+\varepsilon\right)
$$

and the after-tax rate of return earned by the national firm is $\left(1-\tau^{B}\right) r^{B}$. The investor with the highest productivity gain from controlling an asset before taxes has also the highest valuation of the asset after taxes, resulting in an undistorted allocation of ownership even in the presence of taxation.

In order for a system to achieve national ownership neutrality (NON), that is a situation where taxation does not distort the ownership pattern of assets similar to CON, but governments are interested in maximizing national welfare (similar to $\mathrm{NN}$ ) instead of global efficiency, foreign income needs to be exempted from taxation. The rationale provided by Desai and Hines (2004) rests on the insight that outbound foreign investments are decoupled from domestic investments - as capital stocks are assumed to be fixed - and thus any tax policy maximizing the productivity of foreign and domestic investments conforms with NON. The conformity of exempting foreign source income with NON serves as a potential explanation for the increasing number of high-income countries that have switched to the exemption method during the last decade. Figures from the PWC Worldwide Tax Summaries on the 
prevalence of the exemption method report that out of 37 high-income countries, 19 had an exemption system in 1998, and 27 had one in 2008 (see Devereux, Fuest, and Lockwood, 2015).

In the situation where tax policy affects the international capital allocation - which is an empirically validated insight - CON and NON are no longer satisfied, if foreign source income is tax exempt.

A copula linking the "old" views by Richman (1963) and Feldstein and Hartman (1979) and the "new" view of Desai and Hines (2003 and 2004) is provided in Becker and Fuest (2010) and the recent work by Devereux, Fuest, and Lockwood (2015). In the latter work, the authors develop a theoretical model in which FDI may take the form of either greenfield investments or acquisitions. In addition, the MNE is endowed with an initial stock of a mobile factor which is required for production. Additional units of the mobile factor can be hired incurring convex costs of adjustment. The mobile factor links investment activity at home and abroad. If adjustment costs of the fixed factor are negligible, investment at home and abroad are decoupled, whereas in the limiting case of prohibitively high adjustment costs investment at home and abroad are traded off on a one-to-one basis. Moreover, in line with the analysis of Desai and Hines (2003 and 2004), the MNE has an ownership advantage, i.e., it may generate a higher output than the previous owner of the asset. The government has two kinds of instruments: the statutory tax rate on foreign-source income and an allowance on domestic and foreign asset purchase. The model captures simultaneously the two margins of relevance, namely, the international allocation of capital, which is central to the concepts of CEN, CIN, and NN, and also the allocation of ownership rights, the core issue in the work by Desai and Hines on CON and NON. The model shows that the taxation of foreign source income should be such that an optimal allocation of the mobile factors between home and foreign is ensured. In line with the concept of CEN and NN, a globally optimal allocation of the mobile factor requires worldwide taxation coupled with the credit method, whereas national optimality requires the deduction method. Ownership neutrality is established, i.e., domestic and foreign asset purchases remain undistorted by the tax, if a cash-flow tax on domestic investment and a cross border cash-flow tax on foreign investments is implemented. In general, a cash-flow tax requires that all real expenditures are deductible from the tax base and that only the excess rent, in the example the rent due to the ownership advantage, $\varepsilon$, is subject to taxation. For national optimality, the cross-border cash-flow tax should be set at the domestic tax rate. For global optimality, the cross-border cash-flow tax needs to be set equal to the tax rate in the destination country of the outbound investment.

Even though the approach by Devereux, Fuest, and Lockwood (2015) is able to integrate the different views on taxing foreign source income, the resulting recommendations are not aligned with actual practice of exempting foreign source income. To account for this discrepancy, the authors provide an extension to their model showing that in a world, where administrative costs of taxation exist, countries will jointly agree on the exemption method under certain conditions. 


\section{Bilateral tax law as a remedy of double taxation}

Around the globe, governments seek to reduce barriers to inbound FDI in many ways. The reason is that foreign firms provide access to pools of knowledge and ideas, and, hence, a growth potential through job and revenue generation, which would not be accessible without the cross-border activity of MNEs. Tax incentives - or the removal of deterrents associated with discriminatory taxation - are a key element in the catalogue of instruments governments can use. The signing of double-tax treaties (DTTs) is one way of creating tax incentives. These treaties contain various provisions regulating the method of double-taxation relief (exemption, credit, and deduction; see Section 2.a), the margins of activity for which double taxation is relieved (royalty payments, interest payments, capital gains or dividend income), and the degree to and mechanism by which information exchange between tax authorities is granted. By this design, DTTs may have a foreign-investment-attracting effect - through their reduction of effective taxation by double-taxation relief - as well as a foreign-investment-deterring effect - since they limit the degree to which taxation can be evaded through information-exchange provisions. However, the effectiveness of DTTs in these domains does not only depend on their very content but also on the unilateral provisions applying and the institutional environment established in the signatory countries: to the extent that some countries apply tax exemption unilaterally (whereby foreign-earned income will not be taxed at all in the parent country), DTTs may not provide a double-taxation relief, and the relief may be - and often is - asymmetric between signatories; to the extent that anti-taxavoidance institutions are not well developed in the signatory countries, regulations about the exchange of information in DTTs may be irrelevant, and, again, the consequences may be asymmetric between signatories in spite of the provisions applying to both signatories in same way. In general, there is a notion that DTTs, to the extent that they are designed and crafted in a way that is largely dictated by a handful of developed economies, do not only benefit countries asymmetrically, but they even may entail costs for some signatories (see Dagan, 2000, p. 947). Apart from the asymmetric effects on signatory countries, it is acknowledged that DTTs - akin to other treaties granting preferential market access such as preferential trade agreements (PTAs) or bilateral investment treaties (BITs) - have activity-creating as well as activity-diverting effects. The latter are typically unintended replacement effects of economic transactions between signatory and third, non-signatory countries. Hence, by this token some of the economic activity stimulated by DTTs (and other types of bilateral economic agreements) simply replaces earlier activity with countries outside of the treaty or agreement.

In the post-World-War-II period, the amount of DTTs signed has been massive and the pattern has been similar to the formation of BITs or PTAs. For instance, Bösenberg, Egger, and Erhardt (2016) report that in the years 1970, 1990, and 2010 the number of DTTs that had been in force were 324, 1,180, and 2,597, respectively. In the same years, the numbers of BITs in force were 85, 402, and 5,112, and the numbers of PTAs were 84, 916, and 2,855, respectively. Hence, especially the years from the mid- 
nineties of the previous century point to an enormous increase in the demand for and supply of preferential market access through various sorts of treaties.

Akin to other preferential economic agreements, there are three views on DTTs: on the positive side, treaties may create new economic activity to the extent that such activity is distorted in their absence; on the neutral side, many countries operate systems which prevent such distortions in the first place (e.g., some countries unilaterally apply tax exemption to all foreign-earned income), so that treaties are superfluous; on the negative side, strong treaty partners may (ab-)use treaties to impose undesired rules on weaker partners, and treaties may divert activity from non-signatory to signatory partners, even though under the same treatment this activity would happen with the non-signatory partner.

\section{5.a. Economic behavior that is addressed in bilateral tax law}

When considering earlier work on DTTs, it appears that they are viewed to aim at an extremely wide range of activities. For instance, Hugh and Tillinghast (1992, p.1) argue that the "principal function of income tax treaties is to facilitate international trade and investment by removing - or preventing the erection of - tax barriers to the free international exchange of goods and services and the free international movement of capital and persons." In a similar vein, the OECD (2000, p.50) suggests that the "purpose of double taxation conventions is to promote, by eliminating international double taxation, exchanges of goods and services, and the movement of capital and persons." Hence, the view held is that DTTs, while directly only addressing foreign-earned income and its tax and information treatment, do and even are supposed to affect other margins than just direct investment such as trade in goods and services and, eventually, even the cross-border movement of other factors than capital. Indeed, the latter is what is found in Egger and Wamser (2013), who identify relatively large effects of DTTs, apart from direct investment, on aggregate bilateral trade, even bigger ones than most of the (relatively shallow) preferential trade agreements are able to achieve.

Over the past few years, economists provided plenty of evidence from select countries that most of the business activity in any economy is done by only a few firms (see, e.g. Bernard, Jensen, Redding, Schott, 2007; Gabaix, 2011), and most of these firms are multinational in scope in the sense that they operate foreign affiliates all over the world. Hence, most of the revenues, the employment, the innovations, the investment, the trade in goods and services, etc., happens in and by a relatively small percentage of the firms in a country. Clearly, since these firms tend to be relatively old, the economic growth - through entry and exit - is to a larger extent contributed by smaller and younger enterprises. In any case, the large size and scope of a small percentage of firms means that any policy that affects these firms will affect all the activities they carry out, namely, total revenues, profits, employment, goods and services trade, foreign investment, etc. Since DTTs mainly address foreign-earned income which is mainly 
generated by the largest firms in an economy (see Helpman, Melitz, and Yeaple, 2004), we would expect them to affect all large-firm economic outcomes to the extent that they have any effect.

Apart from the overarching importance of DTTs as a policy instrument which is particularly relevant for large firms, these treaties address three specific economic outcomes: dividend payments, interest payments, and royalty payments. Provisions on dividend payments affect the extent to - and the cost at - which firms may repatriate profits among units which belong to the same entity (see Egger, Merlo, Ruf, and Wamser, 2015). Provisions on interest payments affect the profitability of lending, eventually, to units in the same company, among signatory countries. Provisions on royalty payments affect the profitability of an ownership of knowledge in a broad sense (patents, trademarks, etc.) and the sales of its fruits, typically to units in the same company, among signatory countries. An issue with all these outcomes is that they are known to be used by companies to shift profits to low-tax affiliates and countries within the firm in order to avoid or evade taxation. Hence, the degree to which governments grant tax reductions in DTTs on these outcomes affects the degree to which firms will want to use these outcomes as instruments for global tax avoidance. And since the large firms operate in many countries, they can use the global network of DTTs to let profits and earnings travel to the point where taxes are saved to the largest extent.

In any case, Bösenberg, Egger, and Erhardt (2016) summarize the DTT characteristics with respect to dividend, interest, and royalty tax treatment, in more than 3,300 DTTs that were signed among 187 signatories between 1900 and 2013 (noting that the potential number of signatories has changed in the course of history, e.g., with the dissolution of the Soviet Union and the formation of the successor countries) in English language. They report on the preference margins - i.e., the gap in tax rates in percent - applying to dividends, interest, and royalties for the years 2000 and 2010 . Their figures suggest that preference margins on all outcomes declined over that period, since unilaterally applying tax rates tended to decline, too. Specifically, the margins on dividends fell from $6.63 \%$ to $4.56 \%$, the ones on interest fell from $10.29 \%$ to $8.28 \%$, and the ones on royalties fell from $11.26 \%$ to $8.78 \%$. These numbers pertain to the network of all treaties. In absolute as well as in relative terms that reduction in preference margins tended to be larger whenever European signatories were involved and it tended to be smaller whenever (South- and North-) American signatories were involved. Hence, European signatories reduced the generosity of their DTTs the most, in part also because they had to unilaterally reduce company taxation a lot over the time span 2000-2010 due to the increased competition for firm location by the Central and Eastern European Countries, which started in the mid-nineties. 


\section{Forms and remedies of tax avoidance of multinational enterprises:}

\section{6.a. Profit shifting: transfer pricing, debt shifting, and other forms of profit shifting}

The enormous number of DTTs signed over the last century (see Bösenberg, Egger, and Erhardt, 2016) has certainly mitigated the double taxation of foreign source income. Nevertheless, even without any double taxation of foreign source income differences in the level of corporate tax rates across countries allow MNEs to benefit from tax avoidance by exploiting these differences.

There is multiple indirect and more direct evidence that MNEs exploit cross country tax rates to reduce their tax burden. The most common mechanism for MNEs to transfer profits away from high-tax towards low-tax jurisdictions involve the manipulation of transfer prices, internal debt shifting, and royalty payments for intangible assets such as trademarks or intellectual property (e.g., patents).

Income shifting via transfer prices implies that an MNE overprices (underprices) the internally traded good sold in the low-tax (high-tax) jurisdiction and purchased in the high-tax (low-tax jurisdiction). In doing so, the MNE is able to increase (reduce) the income generated in the low-tax (high-tax) jurisdiction and simultaneously reduce (increase) income in the high-tax (low-tax) jurisdiction. Tax avoidance measures such as the arm's length principle, Article 9 of the OECD Model Tax Convention (OECD, 2014), stipulate that prices used for internal transaction of MNEs are supposed to be established on a market-value basis. This provision aims at preventing excessive profit-shifting through internal transactions. However, it becomes futile in situations where no close substitute for the internally traded good is traded on markets and thus no objective benchmark for the internal transfer price exists.

Internal financing is another suitable vehicle for shifting income between differently taxed units of an MNE. The entity located in the low-tax country grants an internal loan to another entity of the MNE located in the high-tax country. The interest paid on the internal loan is tax deductible in the high-tax country and, hence, reduces the tax due there. Additionally, the interest payment directly reduces taxable income in the high-tax country. Interest income received in the low-tax subsidiary is subject to taxation. The benefit from exploiting the tax differential through internal debt becomes larger the higher the interest rate charged on the internal loan is. Upward manipulation of this rate might, however, be difficult, since financial markets may provide information on plausible interest spreads for this kind of internal transactions.

Finally, a third channel of income shifting is through royalty payments and requires the existence of an intangible asset, mostly an intellectual property right, e.g., on a patent or a trademark. In order to enable a transfer of income from the high-tax towards the low-tax jurisdiction, the intangible asset has to be transferred to a low-tax jurisdiction. As a consequence, royalty payments for the use of the intangible input reduce taxable income in the high-tax jurisdiction and an intended income flow towards the lowtax jurisdiction is generated. 
The quantification of tax-motivated income shifting is a tricky task. Identification strategies often have to rely on indirect measures to quantify profit shifting of MNEs. The most influential indirect approach in the context of MNEs dates back to Hines and Rice (1994) and Grubert and Mutti (1991) and is based on the idea of comparing the pre-tax profitability of subsidiaries located in high-tax and low-tax jurisdictions. Specifically, a subsidiary's pre-tax profit is perceived to consist of two components, first, profit generated through the production process, i.e., the utilization of production factors such as capital and labor, and second, shifted profits. The amount of shifted profits is sensitive to tax incentives, such as the tax-rate differential across countries, and determines whether profits are shifted into or out of a subsidiary. Analyzing aggregate reported profitability of US affiliates in different foreign locations in 1982, Grubert and Mutti (1991) find that US-owned affiliates located in high-tax countries exhibit a lower profitability. Using the same data and accounting for capital and labor inputs, Hines and Rice (1994) find that a one percentage point higher tax rate is associated with a reduction of reported beforetax profits by 3 percent. An extensive survey on early studies analyzing the profit shifting behavior of US MNEs using aggregate country-level data is found in Gordon and Hines (2002).

With the increased availability of micro-level data, more recent studies rely on unconsolidated firmlevel, panel data and analyze the change in an affiliate's pre-tax s profitability in response to corporate tax rate changes. The magnitude of tax-motivated income shifting reported in these more recent studies is about three times smaller compared to the older studies which relied on aggregated country level data (see Dharmapala, 2014). One explanation for the substantially smaller estimates for profit shifting reported in the more recent studies is that data availability allows to control for unobserved timeinvariant differences across entities such as country-specific and industry-specific factors. Dharmapala (2014) provides a detailed overview of this more recent literature on the profit-shifting behavior of MNEs which resorts to firm-level data. Heckemeyer and Overesch (2013) collect 238 estimated semielasticities from 25 different studies, including the earlier ones resorting to country-level data and the more recent ones, and conduct a meta-analysis finding a semi-elasticity of 0.8 , in absolute term, as consensus estimate. Accordingly, an increase in an affiliate's host country's corporate tax rate by 10 percentage points lowers reported pre-tax profit of the affiliate by 8 percent. This figure is slightly lower than the value of 1.31 reported by Huizinga and Laeven (2008) as an overall, European-wide semielasticity of pre-tax profits with respect to top statutory tax rates. The latter authors analyze crosssectional firm-level data from the Amadeus database for 1999 and estimate profit shifting elasticities for different European countries as well as for Europe overall.

Alternative approaches to identify profit shifting of MNEs are presented by Dharmapala and Riedel (2013) and Egger, Eggert, and Winner (2010). Dharmapala and Riedel analyze the change in subsidiary profits resulting from an exogenous earning shock of the parent firm. The underlying hypothesis is that an exogenous positive shock in parent income will be shifted only towards subsidiaries with tax rates lower than the parent. Therefore, high-tax subsidiaries of the MNE serve as a control group to account 
for non-tax reasons affecting a subsidiary's income after parent's income has increased. The estimate by Dharmapala and Riedel (2013) suggests that a 10 percentage increase in parent's income raises the profit of low-tax subsidiaries of 0.4 percent. Egger, Eggert, and Winner (2010) try to identify incomeshifting of MNEs by comparing corporate tax payments of MNEs vis-à-vis national firm conglomerates. To account for the endogeneity of the ownership mode the authors apply matching methods. Their estimates show that foreign-owned subsidiaries pay on average about 32\% lower taxes than their domestically-owned twin in a host country with a statutory corporate tax rate of $39 \%$ or higher.

Corporate losses play a crucial and possibly unexpected role in explaining profit shifting behavior of MNEs. The existence of loss-making affiliates lead to reversed profit shifting, i.e., profits may be shifted from the-low tax to a high-tax jurisdiction (DeSimone 2017, Hopland, Lisowsky, Mardan, and Schindler, 2015). The rational for this finding rests on the fact that the marginal tax rate in the loss making, high-tax subsidiary is zero, and thus shifting profits from the low-tax subsidiary into the loss making subsidiary results in tax savings. Koethenbuerger, Mardan, and Stimmelmayr (2016) show that with the existence of loss-making affiliates, profit shifting may result in real investment effects in the low- and high-tax affiliate, a finding which has thitherto not been established in the literature. The possibility of reverse profit shifting further results in a concentration around zero income for affiliates of MNEs. Specifically, affiliates of MNEs report lower profits when running profits, and lower losses when running losses, compared to national firms, a finding first described by Grubert, Goodspeed, and Swenson (1993). The empirical relevance of loss-making subsidiaries is, for instance, documented in Hopland, Lisowsky, Mardan, and Schindler (2015), who report that the portion of loss-making affiliates may be as large as 30 to 50 percent of all entities of an MNE. These authors also provide evidence that MNEs with loss-making affiliates are able to shift profits ex-post, that is, after losses have occurred. Hence, neglecting the issue of reversed profit shifting leads to substantial biases in the estimated profitshifting measures, given the empirical relevance of loss-making affiliates.

In addition to the empirical studies quantifying profit shifting behavior of MNEs based on the comparison of affiliate profitability in low- and high-tax jurisdictions, several papers have made an attempt to measure profit shifting directly by investigating the different channels of profit shifting described above.

For instance, Cristea and Nguyen (2015) analyze Danish firm-level trade data and find that firms, after having set up an affiliate in a low-tax country, reduce unit values of exports to these affiliates by between 5.7 to 9.1 percent, on average. Davies, Martin, Parenti, and Toubal (2014) employ French data and show that tax avoidance through transfer pricing disappears, if exports to tax havens are disregarded. In these data, income shifting is driven by a relatively small group of only 450 firms to ten tax havens. This figure is consistent with the finding of Egger, Merlo, and Wamser (2014), who use a stochastic mixture model to learn how big the fraction of actually tax-avoiding MNEs is. Their results are based on German data and suggest that only the largest firms - which account for a big share of foreign assets - 
engage in profit shifting. Lohse and Riedel (2013) study the effectiveness of tightened transfer pricing legislations and find that transfer pricing rules significantly reduce shifting activities towards low-tax affiliates through distorted intra-firm transfer prices.

Evidence on profit shifting via internal debt suggests that this channel is not the dominant mechanism used for profit shifting. Heckemeyer and Overesch (2013) provide evidence that non-financial shifting mechanisms account for $72 \%$ of the overall pre-tax profits whereas $28 \%$ can be attributed to financial shifting channels such as intra-company debt. One explanation for the lesser importance of internal debt vis-à-vis transfer pricing for profit shifting rests on the fact that internal debt holdings tend to be small and thus the volumes of income shifted via this mechanism (consisting of the interest payment on the internal debt) is also relatively small, as argued by Riedel (2014). Büttner and Wamser (2013) also confirm, using data on German MNEs, that internal debt is a rather unimportant vehicle for profit shifting which they attribute partly to German controlled foreign corporation (CFC) legislation. Møen, Schindler, Schjelderup, Tropina (2011) provide more detailed insight on the mechanism of debt shifting by accounting for internal and external debt shifting in a theoretical model which is tested against German firm data.

Recent tax policies of various EU countries, which stipulate a reduced tax rate for income earned on intellectual property such as patents and licenses, have stimulated the research on profit shifting via valuable intangible assets. Most of the existing research on this relies, however, on indirect evidence by analyzing to which extent the location of patent holdings across group affiliates is distorted by corporate tax differentials. In this spirit, Dischinger and Riedel (2011), the first contribution in this field, analyze firm-level data of European MNEs and find an increase of a subsidiary's intangible property investment by $1.7 \%$ in response to a decline in the average tax differential vis-à-vis other group affiliates by 1 percentage point. With regard to patent location, Karkinsky and Riedel (2012), who analyze corporate patent holdings of European MNEs, find that the corporate tax rate differential to other group members negatively affects the number of patent applications filed by a foreign affiliate. They quantify the effect by a semi-elasticities of around -3.5. Griffith, Miller, and O'Connell (2014) estimate a mixed logit model and investigate how the ownership of intellectual property responds to policy reforms that provide preferential tax treatment to income arising from patents (co-called paten-box systems). The authors find strong effects resulting from the introduction of a patent box system on the location of new intellectual property. Based on simulation analysis, the policy is argued to be associated with a substantial loss of tax revenues collected from patent income - due to the reduced tax rate granted on patent income. Bösenberg and Egger (2017) point out a problem with this kind of research: it uses effective marginal tax incentives (which address investment at the intensive margin) to explain location decisions, which are associated with an extensive investment margin. They illustrate that the correlation between effective marginal and effective average tax incentives towards R\&D are not highly correlated 
and, using patent filing and patent trading as outcome, effective marginal tax incentives appear to be more relevant for location decisions of knowledge in comparison to effective marginal tax incentives. Koethenbuerger, Liberini, and Stimmelmayr (2016) analyze the impact of the tax-induced re-location of intellectual property due to patent box systems on profit shifting of MNEs. The authors find a roughly 6 percent larger profit for affiliates belonging to an MNE with historical patent ownership and being located in a country with a patent box system in place vis-à-vis affiliates of MNEs which do not own patents.

\section{6.b Bargaining with home- and host-country governments}

In spite of it being illegal, some governments engage in harmful tax competition by offering firms socalled "sweetheart tax deals", which are discriminatory between firms and do neither comply with the rules on international commerce governed by the World Trade Organization (WTO) nor the rules agreed on at other supra-national organizations such as the Organization of Economic Cooperation and Development (OECD) or the European Union (EU). Hence, not only firms engage in harmful tax planning but also some governments engage in illegal practice to attract firms for the sake of job creation and the creation of benefits associated with other tax bases (such as labor income).

E.g., such practice is documented by ITR Weekly (2004) for France or by The Telegraph (2016), but it does not feature prominently in academic research (see Egger, Rydzek, and Strecker, 2016, for an empirical approach to identify the economic size of this problem).

\section{6.c Remedies of tax avoidance: transfer-pricing rules, controlled-foreign-company legislation, and thin-capitalization rules}

In Section 4, while acknowledging potentially detrimental effects of DTTs (and other preferential treaties), we made the case that the main intention of DTTs was one to stimulate economic activity. However, MNEs are known to avoid taxation in various ways by profit shifting (see, e.g., Huizinga and Laeven, 2008; Weichenrieder, 2009; Egger, Eggert, and Winner, 2010), and a side effect induced by DTTs may be that they stimulate not only intended but also unintended activity associated with tax avoidance, thereby facilitating an abuse of a generous tax treatment of MNEs. In order to limit the latter, specific provisions on transfer pricing (the specific setting of prices on intermediate goods and services with an intention to avoid profit taxation), on so-called passive income (i.e., an income that does not relate to the main activity of the company such as renting out facilities to subsidiaries and affiliates), and on interest payments may be formulated and apply. These provisions are transfer-pricing rules, controlled-foreign-company (CFC) legislation, and thin-capitalization (Thin-Cap) rules. 


\section{Transfer-pricing rules}

One way of avoiding taxes for MNEs is to charge prices on within-the-firm-traded intermediates (in general, tangible or intangible, but in this context mostly tangible) in a way so as to shift profits to lowtax locations. Then, it is up to tax authorities to compute a reasonable comparison price that may serve as a benchmark to compare actually charged prices to. Customary methods are the comparable uncontrolled price method (by which the reference price is that of a non-MNE in the same market; this is also referred to as the arm's-length principle), the resale price method, and the cost-plus method. Tax authorities may ask firms to submit a documentation of their pricing relative to one or a mix of those methods. However, every one of these methods involves problems of its own. For instance, Devereux and Keuschnigg (2013) pointed out that MNEs might charge a price on intermediate goods within the firm which differs from the reference price of a domestic firm for different than tax reasons. Then, this (unobservable) price should be used as a reference and using a national firm's price as a reference might bias MNE firm behavior in an unintended way.

\section{Controlled-foreign-company legislation (CFC rules)}

CFC rules are formulated to remove an exemption of certain kinds of foreign income from the taxation in a firm's home country. Hence, they partly or fully undo what is eventually granted unilaterally or bilaterally in DTTs. In particular, CFC rules limit or remove the exemption of foreign income that is associated with so-called passive investments and an associated tainted income as well as paper profits (see Nicodème, 2009). The latter is an income which does not flow from a firm's core business. For instance, imagine a big MNE whose core business is the production of pharmaceuticals. Suppose this firm runs affiliates around the globe, some of which are located in high-tax and others in low-tax jurisdictions, and the headquarters reside in Germany - a medium-to-high-tax country. Then, it would be profitable for all high-tax affiliates in the company to rent buildings and machinery from low-tax entities within the firm at a particularly high rental price. This would allow the firm to shift eventually all of its profits in high-tax countries to the low-tax jurisdictions. Such an activity is deemed harmful tax-avoidance practice by the OECD (1998), which recommends taxing such passive income and not granting exemption. The OECD (1998, pp. 40f.) suggests implementing CFC rules to avoid such practice and argues that "countries that do not have such rules [should] consider adopting them and that countries that have such rules [should] ensure that they apply in a fashion consistent with the desirability of curbing harmful tax practices.” The OECD (2013) started engaging in an action plan against tax-base erosion and profit shifting (BEPS), where it particularly recommends strengthening CFC rules as one means to limit harmful tax practice. Accordingly, since the aforementioned firm's main business is in and active income comes from sales of pharmaceuticals, the headquarters jurisdiction (Germany) might want to establish a CFC rule which does not exempt the profits from renting in lowtax jurisdictions from the taxation at home. 
It is widely acknowledged that CFC rules are an important ingredient of tax law at times where tax avoidance is perceived to be increasingly damaging and the concentration of tax burdens on fewer and fewer immobile tax bases may reduce compliance there as well. Nevertheless, research on these rules is relatively scarce. To give a few examples, Altshuler and Hubbard (2003) illustrated that the US Tax Reform Act of 1986 established CFC rules which powerfully reduced the inclination of firms to defer US taxes on financial services income from affiliates in low-tax jurisdictions. However, Altshuler and Grubert (2006) and Mutti and Grubert (2006) found later that MNEs started using hybrid entities to counteract the associated anti-abuse provisions. Ruf and Weichenrieder (2012) found that German CFC legislation indeed reduced the use of passive income to shift profits. However, Egger and Wamser (2015) found that such rules do not only deter passive income but also active investments, which is an unintended side effect.

In general, a precise measurement of the empirical consequences of CFC rules is difficult due to the complexity of their design. In many empirical studies, CFC rules are portrayed in an overly simplistic way. Egger and Wamser (2015) illustrate for the example of Germany that the rules are tremendously complicated and CFC treatment (i.e., the lack of exemption of foreign-earned passive income) does not only depend on the relative magnitude of such income on a given site (in a given affiliate) but also across all units in the company.

\section{Thin-capitalization rules (Thin-Cap rules)}

Multi-plant firms or firms with affiliates may use the internal capital market to finance investments at a given location. With MNEs and a cross-border ownership of affiliates this is particularly interesting as differences in financial markets and in interests prevail across locations. In conjunction with tax differences across jurisdictions and the deductibility of interest payments from profits, this means that borrowing by units in high-tax countries from ones in low-tax countries within the firm may help to reduce the firm-wide tax burden.

For that reason, high-tax countries institute provisions in order to restrict the tax avoidance associated with inter-company loans within the same MNE. The associated provisions are referred to as "thincapitalization rules" or "earning stripping rules" and they are meant to limit adverse financial firm behavior for the sake of tax avoidance (see Fuest and Hemmelgarn, 2005; Panteghini, 2006; Merlo and Wamser, 2014). The problem with such rules is, though, that there is a potential trade-off between the goal of limiting the loss of tax revenues and limiting the financial flexibility through thin-capitalization rules (see Overesch and Wamser, 2010).

The results in Overesch and Wamser (2010), Büttner, Overesch, Schreiber, and Wamser (2012) suggest that thin-capitalization rules are a powerful policy tool to limit profit shifting of MNEs. However, the 
findings by the same authors point to some adverse effects on the intensive margin of foreign investment as well. Moreover, the findings in Merlo, Riedel, and Wamser (2015) suggest that stricter thincapitalization rules reduce the propensity for a firm to set up its first affiliate in a given country and, hence, such rules adversely affect the extensive margin of foreign investment. The same authors find evidence of spillover effects, whereby lower thin-cap-rule-induced investment propensities in one country mean higher investment propensities in third countries. Hence, there may be some freeriding of countries as recipients of direct investment which in the absence of thin-cap rules would have gone to other countries.

\section{Conclusions}

This chapter provides a survey of issues which emerge with the taxation of multinational enterprises. It addresses taxes which affect multinational firms directly and focuses on provisions and incentives which relate to the profits and investments of such firms directly. It surveys positive as well as normative principles of such taxation and incentives, relates to tax-avoidance practices, and discusses their remedies.

The increasing media coverage of corporate tax avoidance by multinational firms not only raised public awareness of this topical issue but also provoked the enactment of several initiatives, such as the OECD/G20 action plan to fight tax base erosion and profit shifting (BEPS, see OECD, 20153). Future research will show how effective these measures will be in closing tax loopholes for multinational tax arbitrage and whether they will lead to an realignment of the taxation of multinational enterprises.

\section{References}

- $\quad$ Altshuler, R., Grubert, H., and Newlon, T. S. (2001). Has US Investment Abroad become more Sensitive to Tax Rates? In: J. R. Hines, Jr. (ed). International Taxation and Multinational Activity. Chicago, IL: University of Chicago Press.

- Antràs, P. and Yeaple, S. R., (2014). Multinational Firms and the Structure of International Trade. In: G. Gopinath, E. Helpman and K. Rogoff (eds). Handbook of International Economics, 4, 55-130, North Holland.

- Baccini, L. and Dür, A. (2012). The new regionalism and policy interdependence. Forthcoming in British Journal of Political Science 42(1).

- Baldwin, R. E., and Krugman, P. (2004). Agglomeration, Integration and Tax Harmonization. European Economic Review 48(1), 1-23.

- Barthel, F., Busse, M., and Neumayer, E. (2010). The impact of double taxation treaties on foreign direct investment: evidence from large dyadic panel data. Contemporary Economic Policy 28(3), 366-377. 
- Barrios, S., Huizinga, H., Laeven, L., and Nicodème, G. (2012). International taxation and multinational firm location decisions. Journal of Public Economics 96(11-12), 946-958.

- Becker, J. and Fuest, C. (2010). Taxing foreign profits with international mergers and acquisitions. International Economic Review 51(1), 171-186.

- Becker, J. and Riedel, N. (2012). Cross-border tax effects on affiliate investment: evidence from European multinationals. European Economic Review, 56(3), 436-450.

- Benassy-Quéré, A., Fontagné, L., and Lahreche-Révil, A. (2003). Tax Competition and Foreign Direct Investment, Working Papers 2003-17, CEPII Research Center, Paris.

- Bergstrand, J.H., Egger, P.H., and Larch, M. (2008). The new expats: economic determinants of bilateral expatriate, FDI, and international trade flows. Unpublished manuscript, University of Notre Dame.

- Bernard, A. B., Jensen, J. B., Redding, S. J., and Schott, P. K. (2007). Firms in International Trade. Journal of Economic Perspectives 21(3), 105-130.

- Blonigen, B. A., Oldenski, L., and Sly, N. (2014). The differential effects of bilateral tax treaties. American Economic Journal: Economic Policy 6(2), 1-18.

- Blonigen, B. A. and Davies, R. B. (2004). The effects of bilateral tax treaties on U.S. FDI activity. International Tax and Public Finance 11(5), 601-622.

- Blonigen, B. A. and Davies, R. B. (2002). Do bilateral tax treaties promote foreign direct investment? NBER Working Paper 8834, National Bureau of Economic Research, Cambridge, MA.

- Büttner, T. and Ruf, M. (2007). Tax incentives and the location of FDI: Evidence from a panel of German multinationals. International Tax and Public Finance 14(2), 151-164.

- Büttner, T., Overesch, M., Schreiber, U., and Wamser, G. (2012). The impact of thin-capitalization rules on the capital structure of multinational firms. Journal of Public Economics 96(11-12), 930938.

- Büttner, T. and Wamser, G. (2013). Internal debt and multinationals' profit shifting - empirical evidence from firm-level panel data. National Tax Journal 66(1), 63-96.

- Chisik, R. and Davies, R. B. (2004). Asymmetric FDI and tax-treaty bargaining: theory and evidence. Journal of Public Economics 88(6), 1119-1148.

- Clausing, K.A. (2016). The Effect of Profit Shifting on the Corporate Tax Base in the United States and Beyond, SSRN Working Paper, http://dx.doi.org/10.2139/ssrn.2685442.

- Cristea, A. D. and Nguyen, D. X. (2015). Transfer pricing by multinational firms: New evidence from foreign firm ownerships. American Economic Journal: Economic Policy, forthcoming.

- Dagan, T. (2000). The tax treaties myth. New York University Journal of Inter-national Law and Politics 32(4), 939-996.

- Davies, R. B. (2003). The OECD model tax treaty: tax competition and two-way capital flows. International Economic Review 44(2), 725-753.

- Davies, R. B. (2004). Tax treaties and foreign direct investment: potential versus performance. International Tax and Public Finance 11(6), 775-802.

- $\quad$ Davies, R. B., Martin, J., Parenti, M., and Toubal F. (2014). Knocking on Tax Haven's Door: Multinational Firms and Transfer Pricing. CESifo Working Paper No. 5132, Munich. 
- Davies, R. B., Norbäck, P.-J., and Tekin-Koru, A. (2009). The effect of tax treaties on multinational firms: new evidence from microdata. World Economy 32(1), 77-110.

- Desai, M. A. and Dharmapala, D. (2008). Tax and Corporate Governance - An Economic Perspective. In: W. Schön (ed.). Tax and Corporate Governance, Springer, Berlin, 13-30.

- Desai, M. A. and Hines, J. R. (2004). Old rules and new realities: Corporate tax policy in a global setting. National Tax Journal 57(4), 937-960.

- Desai, M. A. and Hines, J. R. (2003). Evaluating international tax reform. National Tax Journal 56(3), 487-502.

- Desai, M. A, Foley, C. F., and Hines J. R. (2009). Domestic effects of the foreign activities of US multinationals. American Economic Journal: Economic Policy 1(1), 181-203.

- Desai, M. A, Foley, C. F., and Hines J. R. (2005). Foreign direct investment and the domestic capital stock. American Economic Review 95(2), 33-38.

- Desai, M. A, Foley, C. F., and Hines J. R. (2004). Foreign direct investment in a world of multiple taxes. Journal of Public Economics 88(12), 2727-2744.

- De Mooij, R.A. and Ederveen S. (2003). Taxation and Foreign Direct Investment: A Synthesis of Empirical Research. International Tax and Public Finance, 10(6), 673-693.

- De Simone, L., Klassen, K., and Seidman, J. K. (2017). Unprofitable Affiliates and Income Shifting Behavior. The Accounting Review, forthcoming.

- Devereux, M. P., Fuest, C., and Lockwood, B. (2015). The taxation of foreign profits: a unified view. Journal of Public Economics 125(1), 83-97.

- Devereux, M. P. and Griffith, R. (2003). Evaluating tax policy for location decisions. International Tax and Public Finance 10(2), 107-126.

- Devereux, M. P. and Griffith, R. (1998a). Taxes and the location of production: evidence from a panel of US multinationals. Journal of Public Economics 68(3), 335-367.

- Devereux, M. and Griffith, R. (1998b). The taxation of discrete investment choices. IFS Working Paper W98/16, Institute for Fiscal Studies, London.

- Dharmapala, D., Foley, C. F., and Forbes, K. (2011). Watch What I Do, Not What I Say: The Unintended Consequences of the Homeland Investment Act. Journal of Finance 66(3), 753-787.

- Dharmapala, D. and Riedel, N. (2013). Earnings Shocks and Tax-Motivated Income-Shifting: Evidence from European Multinationals. Journal of Public Economics 97(1), 95-107.

- Dischinger, M. and Riedel, N. (2011). Corporate taxes and the location of intangible assets within multinational firms. Journal of Public Economics 95(7-8), 691-707.

- Dover, R., Ferrett, B., Gravino, D., Jones, E., and Merler, S. (2015). Bringing transparency, coordination and convergence to corporate tax policies in the European Union, EPRS, European Parliamentary Research Service Study PE 558.773.

- $\quad$ Egger, P. H. and Bösenberg, S. (2017). R\&D tax incentives and the emergence and trade of ideas. Economic Policy, forthcoming.

- Egger, P. H., Eggert, W., and Winner, H. (2010). Saving Taxes through Foreign Plant Ownership. Journal of International Economics 81(1), 99-108. 
- Egger, P. H., Keuschnigg, C., Merlo, V., and Wamser, G. (2014). Corporate Taxes and Internal Borrowing within Multinational Firms. American Economic Journal: Economic Policy 6(2), 54-93.

- Egger, P. H., Larch, M., Pfaffermayr, M., and Winner, H. (2006). The impact of endogenous tax treaties on foreign direct investment: theory and evidence. Canadian Journal of Economics 39(3), 901-931.

- $\quad$ Egger, P. H., Loretz, S., Pfaffermayr, M., and Winner, H. (2009a). Bilateral effective tax rates and foreign direct investment. International Tax and Public Finance 16(6), 822-849.

- $\quad$ Egger, P. H., Loretz, S., Pfaffermayr, M., and Winner, H. (2009b). Firm-specific forward-looking effective tax rates. International Tax and Public Finance 16(6), 850-870.

- Egger, P. H. and Merlo, V. (2011). Statutory corporate tax rates and double taxation treaties as determinants of multinational firm activity. Finanz Archiv: Public Finance Analysis 67(2),145-170.

- $\quad$ Egger, P. H., Merlo, V., Ruf, M., and Wamser, G. (2015). Consequences of the new UK Tax Exemption System: Evidence from micro-level data. Economic Journal 125(589), 1764-1789.

- Egger, P. H., Merlo, V., and Wamser, G. (2014). Unobserved Tax Avoidance and the Tax Elasticity of FDI. Journal of Economic Behavior \& Organization 108, 1-18.

- Egger, P. H., Rydzek, B., and Strecker, N. (2016). Estimating bargaining-related tax advantages of multinational firms. Unpublished manuscript, ETH Zurich.

- Egger, P. H. and Wamser, G. (2013). Multiple faces of preferential market access: their causes and consequences. Economic Policy 28(73), 143-187.

- Egger, P. H. and Wamser G. (2015). The impact of controlled foreign company legislation on real investments abroad. A multi-dimensional regression discontinuity design. Journal of Public Economics 129, 77-91.

- Elitzur, R. and Mintz, J. (1996). Transfer pricing rules and corporate tax competition. Journal of Public Economics, 60(3), 401-422.

- Elsayyad, M. (2012). Bargaining over tax information exchange. Working Paper 2012-02, Max Planck Institute for Tax Law and Public Finance, Munich.

- European Commission (2012). The internal market: factual examples of double non-taxation cases, Staff Working Paper, Brussels.

- Feld, L. P., Ruf, M., Scheuering, U., Schreiber, U. and Voget J. (2016). Repatriation taxes and outbound M\&As. Journal of Public Economics 139, 13-27.

- Feldstein, M. and Hartman, D., (1979). The optimal taxation of foreign source investment income. The Quarterly Journal of Economics, 93(4), 613-629.

- Foley, F., Hartzell, J. C., Titman, S., and Twite, G. (2007). Why do firms hold so much cash? A taxbased explanation. Journal of Financial Economics, 86(3), 579-607.

- Fuest, C. and Hemmelgarn, T. (2005). Corporate tax policy, foreign firm ownership and thin capitalization. Regional Science and Urban Economics 35(5), 508-526.

- Gordon, R. H. and Hines, J. R. (2002). International Taxation. In: A. J. Auerbach and M. Feldstein (eds). Handbook of Public Economics 4, 1935-1995, North Holland.

- Gabaix, X. (2011). The Granular Origins of Aggregate Fluctuations. Econometrica 79(3), 733-772. 
- Gorter, J. and Parikh, A. (2000). How Mobile is Capital in the European Union? CPB Research Memorandum no. 172, The Hague.

- Gorter, J. and de Mooij, R. A. (2001). Capital Income Taxation in the European Union: Trends and Trade-Offs. The Hague: Sdu Publishers.

- Griffith, R., Miller, H., and O'Connell, M. (2014). Ownership of Intellectual Property and Corporate Taxation. Journal of Public Economics 112, 12-23.

- Grubert, H., Goodspeed, T., and Swenson, D. (1993). Explaining the Low Taxable Income of Foreign-Controlled Companies in the United States. In: A. Giovannini, R. G. Hubbard and J. Slemrod (eds). Studies in International Taxation, 237-70. Chicago: University of Chicago Press.

- Grubert, H. and Mutti, J. (2000). Do Taxes Influence where US Corporations Invest? National Tax Journal 53(4), 825-839.

- Grubert, H. and Mutti, J. (1991). Taxes, Tariffs and Transfer Pricing in Multinational Corporation Decision Making. Review of Economics and Statistics 73(2), 285-293.

- Hanlon, M., Lester, R., and Verdi, R. (2015). The effect of repatriation tax cost on U.S. multinational investment. Journal of Financial Economics 116(1), 179-196.

- Harford, J., Wang, C., and Zhang, K. (2015). Foreign cash: taxes, internal capital markets and agency problems. Review of Financial Studies, Forthcoming.

- Hartman, D. G. (1984). Tax Policy and Foreign Direct Investment in the United States. National Tax Journal 37(4), 475-488.

- Hasegawa, M. and Kiyota, K. (2015). The Effect of Moving to a Territorial Tax System on Profit Repatriation: Evidence from Japan, GRIPS Discussion Paper 15-09, Tokyo.

- Hebous, S., Ruf, M., and Weichenrieder, A. (2010). The Effects of Taxation on the Location Decision of Multinational Firms: M\&A vs. Greenfield Investments. CESifo Working Paper No. 3076, Munich.

- Heckemeyer, J. H. and Overesch, M. (2013). Multinationals' profit response to tax differentials: Effect size and shifting channels. ZEW Discussion Paper No. 13-045, Mannheim.

- Helpman, E., Melitz, M. J., and Yeaple, S. R. (2004). Export Versus FDI with Heterogeneous Firms. American Economic Review 94(1), 300-316.

- Hines, J. R. (2009). Reconsidering the taxation of foreign income. Tax Law Review 62, 269-298.

- Hines, J. R., (1999). Lessons from Behavioural Responses to International Taxation. National Tax Journal 52(2), 305-23.

- Hines, J. R. (1997). Tax Policy and the Activities of Multinational Corporations. In: A. J. Auerbach (ed.). Fiscal Policy: Lessons from Economic Research. Cambridge MA: MIT Press.

- Hines, J. R. (1996). Altered States: Taxes and the Location of Foreign Direct Investment in America. American Economic Review 86(5), 1076-1094.

- Hines, J. R., and Rice, E. M. (1994). Fiscal Paradise: Foreign Tax Havens and American Business. Quarterly Journal of Economics 109(1), 149-182.

- Hopland, A. O., Lisowsky, P., Mardan, M., and Schindler, D. (2015). Income Shifting under Losses. NHH Discussion Paper, FOR 21, Bergen. 
- Hugh J. A. and Tillinghast, D. R. (1992). Federal income tax project: international aspects of United States income taxation II, proposals on United States income tax treaties. American Law Institute, Philadelphia, PA.

- Huizinga, H., Voget, J., and Wagner, W. (2012). Who bears the burden of international taxation? Evidence from cross-border M\&As. Journal of International Economics 88(1), 186-197.

- Huizinga, H., and Laeven, L. (2008). International Profit Shifting Within European Multinationals. Journal of Public Economics 92(5-6), 1164-1182.

- ITRWeekly, 2004. Vivendi strikes deal on French taxes. International Tax Review, 30 August 2004.

- Johannesen, N. (2014). Tax avoidance with cross border hybrid instruments. Journal of Public Economics 112, 40-52.

- Johannesen, N. (2012). Cross-border hybrid instruments, EPRU Working Paper 2012/02, Copenhagen.

- Karkinsky, T. and Riedel, N. (2012). Corporate Taxation and the Location of Patents within Multinational Firms. Journal of International Economics, 88(1), 176-185.

- Keuschnigg, C., and Devereux, M., (2013). The arm's length principle and distortions to multinational firm organization. Journal of International Economics 89(2), 432-440.

- Kind, H.J., Midelfart Knarvik, K.H., and Schjelderup, G. (2000). Competing for capital in a 'lumpy' world. Journal of Public Economics 78(3), 253-274.

- Krahmal, A. (2005). International Hybrid Instruments: Jurisdiction dependent Characterization. Houston Business and Tax Law Journal, 98-127.

- Keen, M. J. and Konrad K. (2014). The theory of international tax competition and coordination. In: A. J. Auerbach, R. Chetty, M. Feldstein, and E. Saez (eds). Handbook of Public Economics 5, 257328, North Holland.

- Keen, M. and Ligthart, E. J. (2006). Information sharing and international taxation: a primer. International Tax and Public Finance 13(1), 81-110.

- Koethenbuerger, M., Liberini, F. and Stimmelmayr, M., (2016). Is it Luring Profits? The Case of European Patent Boxes. Unpublished manuscript, ETH Zurich.

- Koethenbuerger, M., Mardan, M. and Stimmelmayr, M. (2016). Profit-Shifting with loss-making MNE affiliates. Unpublished manuscript, ETH Zurich.

- Koethenbuerger, M. and Stimmelmayr, M. (2016a). Taxing multinationals in the presence of internal capital markets. Journal of Public Economics 138, 58-71.

- Koethenbuerger, M. and Stimmelmayr, M. (2016b). Tax-Induced Transfer Pricing and Corporate Agency Costs. Unpublished manuscript, ETH Zurich.

- Ligthart, E. J., Vlachaki, M., and Voget, J. (2012). The determinants of double tax treaty formation. Unpublished Working Paper, available at: webwijs.uvt.nl/publications/258672 ext.pdf.

- Lohse, T. and Riedel, N. (2013). Do Transfer Pricing Laws Limit International Income Shifting? Evidence from European Multinationals. CESifo Working Paper Series No. 4404, Munich.

- Macalister, Terry. (2013). "Starbucks pays corporation tax in UK for first time in five years". The Guardian, 23 June [Online]. Available at: https://www.theguardian.com/business/2013/jun/23/starbuckspays-corporation-tax 
- Merlo, V., Riedel, N., and Wamser, G. (2015). The impact of thin capitalization rules on the location of multinational firms' foreign affiliates. CESifo Working Paper No. 5449, Munich.

- Merlo, V. and Wamser, G. (2014). Debt shifting and thin-capitalization rules. CESifo DICE Report, Journal for Institutional Comparisons 12(4).

- Millimet, D. L. and Kumas, A. (2008). It's all in the timing: assessing the impact of bilateral tax treaties on US FDI activity. In: L., Sachs and K. P. Sauvant (eds). The Effect of BITs and DTTs on FDI Flows, Oxford University Press, Oxford.

- Møen, J., Schindler, D., Schjelderup, G., and Tropina, J. (2011). International Debt Shifting: Do Multinationals Shift Internal or External Debt? CESifo Working Paper, No. 3519, Munich.

- Musgrave, P. (1969). United States Taxation of Foreign Investment Income: Issues and Arguments, Cambridge MA, International Tax Program, Harvard Law School.

- Nielsen, S.B., Raimondos-Möller, P., and Schjelderup, G. (2010). Company taxation and tax spillovers: Separate accounting versus formula apportionment. European Economic Review 54(1), 121-132.

- $\operatorname{OECD}(1998,2000,2003,2005,2008,2010 a)$. Model Tax Convention on Income and on Capital: Condensed Version. OECD Publishing, Paris.

- OECD (2010b, 2015). Model Tax Convention on Income and on Capital: Full Version 2010, 2014. OECD Publishing, Paris.

- OECD (2012). Hybrid Mismatch Arrangements: Tax Policy and Compliance Issues, OECD Publishing, Paris.

- OECD (2015). Base Erosion and Profit Shifting, OECD Publishing, Paris.

- Overesch, M. and Wamser, G. (2010). Corporate tax planning and thin-capitalization rules: evidence from a quasi-experiment. Applied Economics 42(5), 563-573.

- Overesch, M. and Wamser, G. (2014). The impact of thin-capitalization rules on external debt usage - A propensity score matching approach. Oxford Bulletin of Economics \& Statistics 76(5), 764-781.

- Panteghini, P.M. (2006). The capital structure of multinational companies under tax competition, CESifo Working Paper No. 1721, Munich.

- PWC, PricewaterhouseCoopers (2013). Evolution of Territorial Tax Systems in the OECD, http://www.pwc.com/us/nes.

- Richman, P. (1963). Taxation of Foreign Investment Income, An Economic Analysis, Baltimore, MD, Johns Hopkins Press.

- Riedel, N. (2014). Quantifying International Tax Avoidance: A Review of the Academic Literature, ETPF Policy Paper No. 2.

- Slemrod, J. (1990). Tax effects on foreign direct investment in the U.S.: evidence from a cross country comparison. In: A. Razin, and J. Slemrod (eds). Taxation in the Global Economy. University of Chicago Press, Chicago, IL.

- Swenson, D. (2001). Transaction Type and the Effect of Taxes on the Distribution of Foreign Direct Investment in the U.S. In: J. R. Hines (ed). International Taxation and Multinational Activity, University of Chicago Press, 89-108.

- The Telegraph, (2016). Belgium's 'sweetheart' tax deals are illegal, says EU. 11 January 2016. 